(ㄷ) Мальцев Д.В., 2021

doi: 10.37321/nefrology.2021.29-01

УДК: 612.017.1:616-008.6

\title{
ГЕРПЕСВІРУСНІ ІНФЕКЦІЇ В НЕФРОЛОГІЇ
}

\author{
МАЛЬЦЕВ Д.В. \\ Національний медичний університет імені О.О. Богомольця \\ Інститут експериментальної і клінічної медицини \\ Київ, Україна
}

Резюме

Вступ. Герпетичні віруси - група опортуністичних ДНК-вмісних вірусних агентів, що володіють властивістю пантропізму, тобто здатністю уражати всі органи і системи людського організму. Не виключення становить й сечовивідна система, тому нефрологи мають віддавати належну увагу проблемі герпесвірус-асоційованих уражень нирок та інших органів сечовиділення. Дана публікація $€$ науковим оглядом результатів клінічних досліджень і повідомлень про клінічні випадки щодо герпесвірусних інфекцій у нефрологічних пацієнтів, що опубліковані протягом останніх років в рецензованих періодичних наукових виданнях, цитованих в авторитетних наукометричних електронних базах даних PubMed i Embase.

Мета. Стаття покликана сформувати у нефрологів сучасне комплексне розуміння проблеми герпесвірусних інфекцій у пацієнтів з хворобами нирок.

Матеріали і методи. Бібліографічний - проведено теоретичний аналіз та здійснено узагальнення даних літератури, проаналізовано фактичний вміст. При дослідженні використано анкетно-опитувальний метод, а також - опис, аналіз, реферування.

Результати та їх обговорення. В статті розглянуті дані щодо прямих герпесвірусних уражень нирок за типом інтерстиційного нефриту і гломерулонефриту. Підкреслено необхідність проведення диференційної діагностики з аналогічними ураженнями нирок автоімунної природи в таких випадках. Також неведені дані щодо непрямих уражень нирок, спровокованих реактивованими герпесвірусами, включаючи тропні до ниркової паренхіми автоімунні, алергічні та імунозапальні реакції, індукцію синдрому пухлинного росту та розвиток лімфопроліферативних синдромів, а також - герпесвірус-асоційовані метаболічні порушення з ефектом нефротоксичності. Окремо подано інформацію про герпесвірусні інфекції у реципієнтів алогенної нирки. Порушені питання нефротоксичності при застосуванні специфічних протигерпетичних хіміопрепаратів у пацієнтів з хронічною нирковою недостатністю.

Висновки. Герпесвірусні агенти є активними фігурантами етіології та патогенезу багатьох хвороб нирок у людей. Їх реактивація із латентного або персистуючого стану зазвичай відбувається в умовах імуносупресії, тому імуноскомпрометовані пацієнти з нефрологічними проблемами $є$ групою ризику з формування ускладнень, зумовлених герпесвірусами.

Ключові слова: віруси простого герпесу, варицелла-зостер вірус, вірус Епштейна-Барр, цитомегаловірус, віруси герпесу 6, 7, 8 типів, інтерстиційний нефрит, гломерулонефрит, трансплантація алогенної нирки.

Вступ. Герпетичні віруси - група опортуністичних ДНК-вмісних вірусних агентів, що володіють властивістю пантропізму, тобто здатністю уражати всі органи і системи людського організму [1, 2]. Не виключення становить сечовивідна система, тому нефрологи мають віддавати належну увагу проблемі герпесвірус-асоційованих уражень нирок та інших органів сечовиділення. Дана публікація є оглядом результатів клінічних досліджень і повідомлень про клінічні випадки, що опубліковані протягом останніх років з цієї теми в рецензованих періодичних наукових виданнях, цитованих в авторитетних наукометричних електронних базах даних PubMed i Embase.
Мета. Стаття покликана сформувати у нефрологів сучасне комплексне розуміння проблеми герпесвірусних інфекцій у пацієнтів з хворобами нирок.

Матеріали і методи. Бібліографічний - проведено теоретичний аналіз та здійснено узагальнення даних літератури, проаналізовано фактичний вміст. При дослідженні використано анкетно-опитувальний метод, а також - опис, аналіз, реферування.

Результати та їх обговорення. Наразі встановлено, що герпесвіруси всіх видів можуть бути залученими до етіології та патогенезу хвороби нирок в організмі людини, однак відомі певні між- 
видові відмінності як в механізмах, так і клінічних формах вірус-асоційованих нефрологічних уражень [1]. Особливістю герпесвірусних інфекцій $\epsilon$ реактивація переважно в організмі імуноскомпрометованих пацієнтів з можливістю залучення різних механізмів пошкодження нирок - прямого ураження завдяки реалізації цитопатичних властивостей вірусу й індукції цитотоксичної імунної відповіді проти патогену в нирковій паренхімі, вірус-індукованих автоімунних реакцій, при яких герпесвіруси виступають триггерами зриву імунної толерантності до ниркових автоантигенів, імунозапальних реакцій, що лежать, наприклад, в основі реакцій відторгнення трансплантату у реципієнтів алогенної нирки та онкологічних уражень нирок, оскільки герпесвіруси $€$ відомими онкогенами при розвитку ряду злоякісних неоплазій в організмі людини. Таким чином, герпесвіруси можуть бути залученими в патогенез різноманітних хвороб нирок, що можуть стати причиною ниркової недостатності. Існує і зворотний бік проблеми - вторинна реактивація герпесвірусів із латентного або персистуючого стану внаслідок розвитку певної, не пов'язаної з герпесвірусами хвороби нирок, яка призводить до стану вторинної імуносупресії з послабленням імунного нагляду над опортуністичними ендогенними агентами. При цьому можуть уражатися реактивованим вірусом інші органи і системи, що поглиблює важкість клінічного стану пацієнта, а також можливе додаткове вірус-індуковане ураження первинно скомпрометованої нирки, у зв'язку з цим посилюються прояви ниркової недостатності. Окремий аспект проблеми герпесвірусних інфекцій в нефрології - переносимість специфічних протигерпетичних хіміопрепаратів у пацієнтів з порушеннями екскреторної функції нирок.

Прямі герпесвірусні ураження нирок (інтерстиційний нефрит, гломерулонефрит). Герпесвірусні інфекції можуть безпосередньо уражати тканину нирок, будучи етіологічними агентами інтерстиційних нефритів, переважно - в імуноскомпрометованих пацієнтів, хоча існують непоодинокі повідомлення про розвиток подібних уражень у пацієнтів без очевидної імуносупресії. Індуковані герпесвірусами нефрити описані як при первинних, так і хронічно активних та реактивованих герпесвірусних інфекціях. Причиною вірусних уражень нирок можуть бути як альфа-, так і бета- і гамма-герпесвіруси людини. Вірус-індуковані інтерстиційні нефрити можуть розвиватися в інтактних власних нирках організму людини, так і в трансплантатах у реципієнтів алогенної нирки. Накопичується інформація, присвячена опису вірус-індукованих гломерулонефритів, при яких слід проводити ретельну диференційну діагностику з відомими автоімунними формами ураження гломерулярного апарату нирок.
Hemmersbach-Miller M. зі спів. описали гострий геморрагічний інтерстиційний нефрит, зумовлений вірусом простого герпесу 1 типу, що розвинувся невдовзі після пересадки алогенної нирки у зв'язку із застосуванням імуносупресивного лікування для попередження імунної реакції відторгнення трансплантату. Вдалося добитися сприятливого результату після курсу в/в ацикловіру та зменшення доз застосовуваних цитостатичних хіміопрепаратів [13]. White W.M. зі спів. повідомили про дисеміновану HSV-1-інфекцію із ураженням нирок у вигляді інтерстиційного нефриту та печінки з розвитком герпесвірусного некротичного гепатиту у 48-річної вагітної на 28 тижні гестації. До цього моменту пацієнтку вважали імунокомпетентною особою. Герпесвірусна інфекція імітувала так званий HELLP-синдром (hemolysis, elevated liver enzymes, low platelets), 3 чим було пов'язано зволікання з протигерпетичною терапією [32].

Majumdar A. зі спів. доповіди про мембранопроліферативний гломерулонефрит, викликаний VZV, у 16-річного імунокомпетентного пацієнта. Відзначалися анасарка, папуло-везикулярний висип на шкірі та нефротичний синдром з масивною протеїурією, що досягала втрати з сечею 16 грам білку за 24 години, та гематурією, а також - нефритичний синдром з піурією. Діагноз гломерулонефриту підтвердили на підставі гістологічного аналізу біоптату паренхіми нирки [20].

Zou G. зі спів. описали розвиток VZVіндукованого гломерулонефриту з нефритичним та нефротичним синдромами та енцефаліту з епілептичним синдромом у 15-річного імунокомпетентного пацієнта. Гістологічний аналіз біоптату нирок виявив ознаки ендокапілярної проліферації з розростанням подоцитів та тубулярним пошкодженням, що було візуалізовано при світлові мікроскопії. За допомогою прямої імунофлуореспенції продемонстровано глобальні гранулярні депозити IgG, IgA, IgM, C3, C1q та фібриногену в мезангії та вздовж стінки гломерулярних капілярів, що наштовхувало н думку про автоімунний характер патологічного процесу. Тим менше, специфічний антиген та MPHK VZV було ідентифіковано в гломерулярних та тубулярних епітеліальних клітинах за допомогою імуногістохімічного аналізу та гібридизації in situ. Також виявили вільні вірусні частинки VZV в паренхімі уражених нирок шляхом електронної мікроскопії. Ці дані дозволили стверджувати про первинність активної VZV-інфекції в індукції імуноопосередкованого патологічного процесу в нирковій паренхімі. МРТ головного мозку демонструвала множинні вогнища ураження в півкулях великого мозку [36].

Wynd E. зі спів. описали розвиток фокального гломерулосклерозу з нефротичним синдромом, викликаного CMV, у 16-річного реципієнта 
алогенної нирки. Іншими клінічними проявами реактивованої CMV-інфекції були лейкопенія та гострий гепатит. Лікування проводили ганцикловіром інфузійно, а потім - валганцикловіром у вигляді перорального курсу [33].

Georgaki-Angelaki Н. зі спів. повідомили про розвиток мембранозної нефропапії у 19-місячної дитини без ознак вторинної імуносупресії. Гломерулонефрит проявлявся у вигляді нефритичного та нефротичного синдромів. Паралельно відзначалася макулопапульозна екзантема та персистуюча лихоманка протягом останніх двох місяців. Діагноз мембранозної невропатії підтвердили на підставі гістологічного аналізу тканини біоптату нирки. ПЛР гістологічного зразку нирки ідентифікувала ДНК CMV. Лікування ганцикловіром призвело до швидкого одужання дитини і відновлення функції нирок [8].

Maiese A. зі спів. опублікували дані про фатальну реактивовану EBV-інфекцію з розвитком менінгоенцефаліту, фокального міокардиту та інтерстиційного нефриту у 74-річного пацієнта без очевидних ознак імуносупресії [19]. Kano. К. зі спів. повідомили про розвиток летального EBVіндукованого мезангіопроліферативного гломеруонефриту в 11-річної пацієнтки без ознак вторинного імунодефіциту. ДНК ЕВV була ідентифікована в клітинах розширених васкулярних просторів навколо тубулярних артерій в зразках тканини нирок, отриманих як при біопсії, так й аутопсії [15].

Як вказувалося раніше, особливістю герпесвірусних інфекцій є можливість уражати нирки за допомогою принципово різних механізмів. Так, Moretti М. зі спів. провели мета-аналіз публікацій в періодичний науковій літературі щодо гострих уражень нирок при первинній EBV-інфекції - інфекційному мононуклеозі. Результати даного мета-аналізу вказують, що EBV може індукувати принаймні 4 різні форми ниркової патології в таких випадках, зокрема - інтерстиційний нефрит, міозит-асоційоване гостре ниркове пошкодження, гемолітичний уремічний синдром та жовтяниця-асоційовану нефропатію [23].

Автоімунні ураження нирок, опосередковані герпесвірусами. Герпесвіруси $є$ визнаними тригерами автоімунних хвороб у людей, в тому числі - автоімунної патології із залученням нирок. Люпус-нефрит $є$ типовим проявом системного червоного вовчаку. Як показують результати останнього мета-аналізу та систематичного огляду рандомізованих контрольованих клінічних досліджень, де проаналізовано результати 33 відповідних випробувань, EBV $€$ тригером зриву механізмів імунної толерантності при розвитку системного червоного вовчаку у людей, завдяки чому тісно залучений до патогенезу люпус-нефриту (рис. 1) [16].

Відомим тригером при розвиткові автоімунного гломерулонефриту є бета-гемолітичний стрептокок групи А. Наразі встановлена тісна асоціація між EBV та ревматогенним стрептококом, тому часто відзначаються мікстінфекції EBV+Streptococcus pyogenes при індукції автоімунного гломерулонефриту. Показано, що мікстінфекція (EBV + Str.) асоційована з більшою кількістю ДНК ЕВV в слині і мигдаликах та набагато вищою експресією BZLF1 (білка літичної EBV-інфекції). Крім того, пептидоглікани стрептококку через вплив на TLR-2 активують EBV 3 латентного стану в інфікованих клітинах лімфобластоїдної лінії мигдаликів (LCLs) [30]. Це аспекти міжмікробної взаємодії при розвитку вказаних мікстінфекцій. Крім того, існує імунологічний аспект цієї проблеми. Зокрема, первинний тотальний дефіцит IgG3 (G3(g) allotype) асоційований 3 первинним вибірковим дефіцитом специфічних IgG2 до полісахаридів стрептококів зі збереженням загального пулу lgG2 (G2(n) negative allotype). Ця характерна для людей генетична асоціація двох первинних дефіцитів субкласів IgG опосередковує добре відому схильність до одночасної активації EBV і бета-гемолітичного стрептококу групи А з формуванням мікстінфекції в мигдаликах, що може стати відправною точкою для індукції асоційованих автоімунних ускладнень [18].

Відповідно до цього, Watanabe T. зі спів. повідомили саме про мікстінфекцію EBV + Streptococcus pyogenes як тригер розвитку гострого автоімунного гломерулонефриту у 16-річної пацієнтки без очевидних ознак вторинної імуносупресії [31]. Subat-Dezulović М. зі спів. описали розвиток постінфекційного гломерулонефриту у 11-річного пацієнта без очевидних ознак вторинної імуносупресії. Серологічні дані вказували на гострі стрептококову та EBV-інфекції напередодні дебюту автоімунного синдрому. Гістологічний аналіз ниркового біоптату демонстрував картину PIGN-типу та додаткові прояви інтерстиційного нефриту, що $€$ характерними проявами стрептокок-індукованого автоімунітету. Проте ПЛР in situ ідентифікувала ДНК EBV у багатьох клітинах ниркової паренхіми, що вказувало на інфікування нирок цим опортуністичним агентом [29].

Проте слід враховувати, що EBV часом може самостійно індукувати автоімунний гломерулонефрит, навіть без участі ревматогенного стрептококку. Наприклад, Meyer Р. зі спів. описали розвиток спочатку гострої автоімунної полірадикулоневропатії, а потім - мембранозного гломерулонефриту на тлі хронічної активної EBVінфекції в 12-річної дівчинки без ознак вторинного імунодефіциту. Вірусемія, сформована EBV, за даними ПЛР крові тривала щонайменше 6 місяців поспіль без вживання будь-яких терапевтичних заходів з цього приводу, що і, найбільш ймовірно, дозволило вірусу реалізувати зрив імунної толерантності до власних антигенів організму пацієнтки [22]. 
(a)

SLE cases control

study/subgroup events total events total
$\%$

OR $(95 \% \mathrm{Cl}) \quad$ Weight

$1.25(0.66,2.39) \quad 9.70$

$0.21(0.03,1.59) \quad 3.12$

$0.35(0.09,1.45) \quad 5.18$

$17.23(2.19,135.39) \quad 3.09$

$1.89(0.50,7.17) \quad 5.52$

$0.09(0.00,1.73) \quad 1.68$

$0.48(0.08,2.75) \quad 3.92$

$0.33(0.01,8.21) \quad 1.48$

$1.25(036,4.34) \quad 5.95$

$27.00(3.17,229.96) \quad 2.92$

$0.60(0.18,2.00) \quad 6.17$

$1.33(0.40,4.40) \quad 6.21$

$2.15(1.15,403) \quad 9.84$

$0.75(0.48,1.17) \quad 11.06$

$0.51(0.09,2.81) \quad 409$

$1.02(0.40,2.62) \quad 767$

$0.30(0.03,3.15) \quad 253$

$0.31(0.03,3.16) \quad 256$

$1.06(0.70,1.61) \quad 10000$

(b)

Filled funnel plot with pseudo $95 \%$ confidence litimts

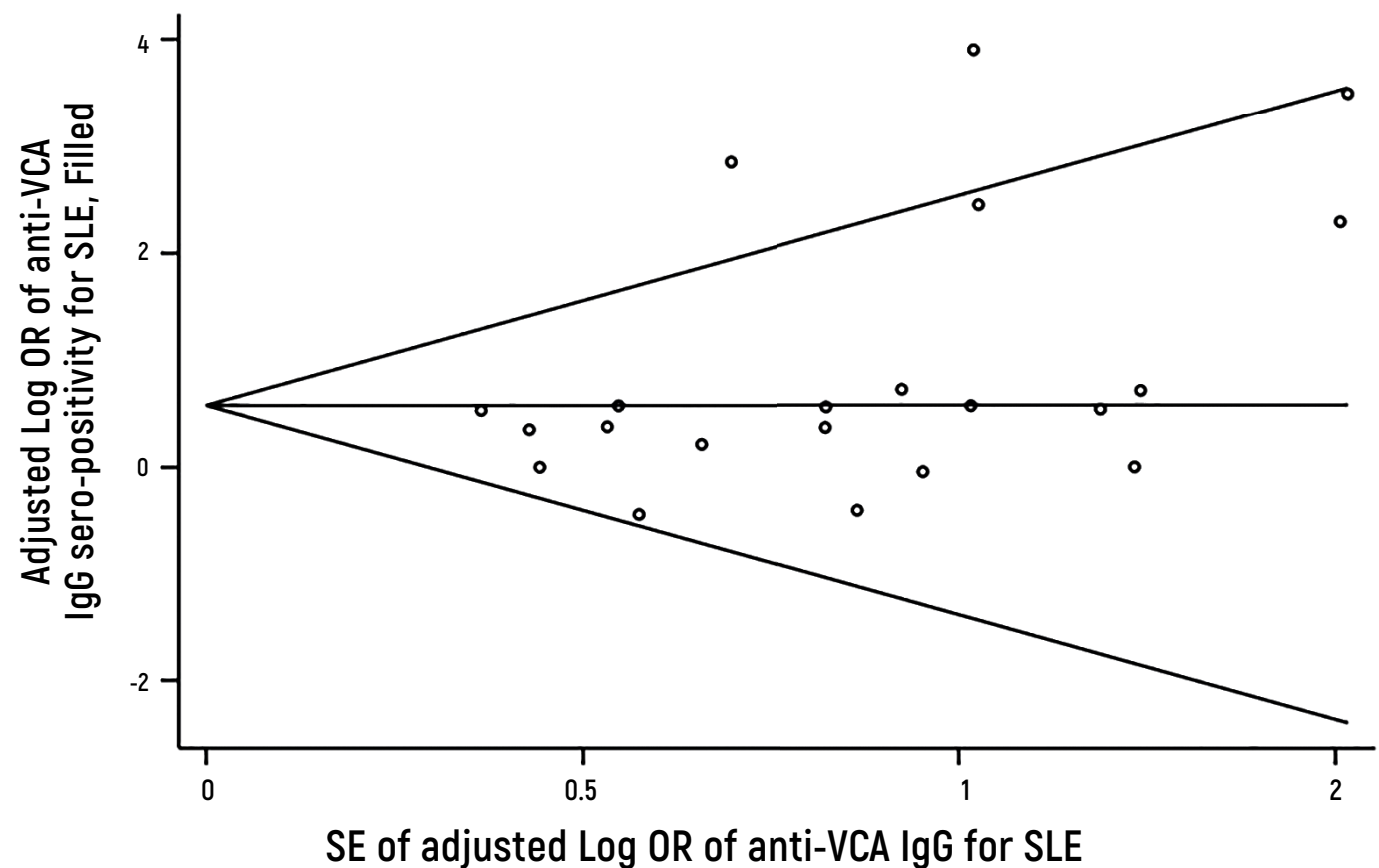

Pиc. 1. Forest plot (a) та funnel plots (b) результатів аналізу серопозитивності anti-VCA IgG EBV при системному червоному вовчаку у людей (за Li Z.-X. Зі спів.)

Алергічні ураження нирок, спричинені герпесвірусами. Наразі встановлено, що герпесвірусні агенти, особливо - HHV-6- та HHV-7, можуть бути тригерами алергічних реакцій за типом сповільненої гіперчутливості, при яких відзначається імуноопосередковане ураження нирок. Передовсім, йдеться про випадки DIHS/DRESS (drug-induced hypersensitivity syndrome/drug reaction with eosinophilia and systemic symptoms) у відповідь на прийом деяких медикаментів з імуносупресивною дією [3, 4]. Aatif Т. зі спів. повідомили про розвиток важкого епізоду DIHS/DRESS у 64-річного імунокомпетентного пацієнта з картиною інтерстиційного нефриту з ознаками ниркової недостатності у відповідь на 8-тижневий курс терапії алопуринолом з приводу персистуючої гіперурикемії. ПЛР крові демонструвала реактивацію HНV-6 за станом вірусемії (рис. 2) [5]. 


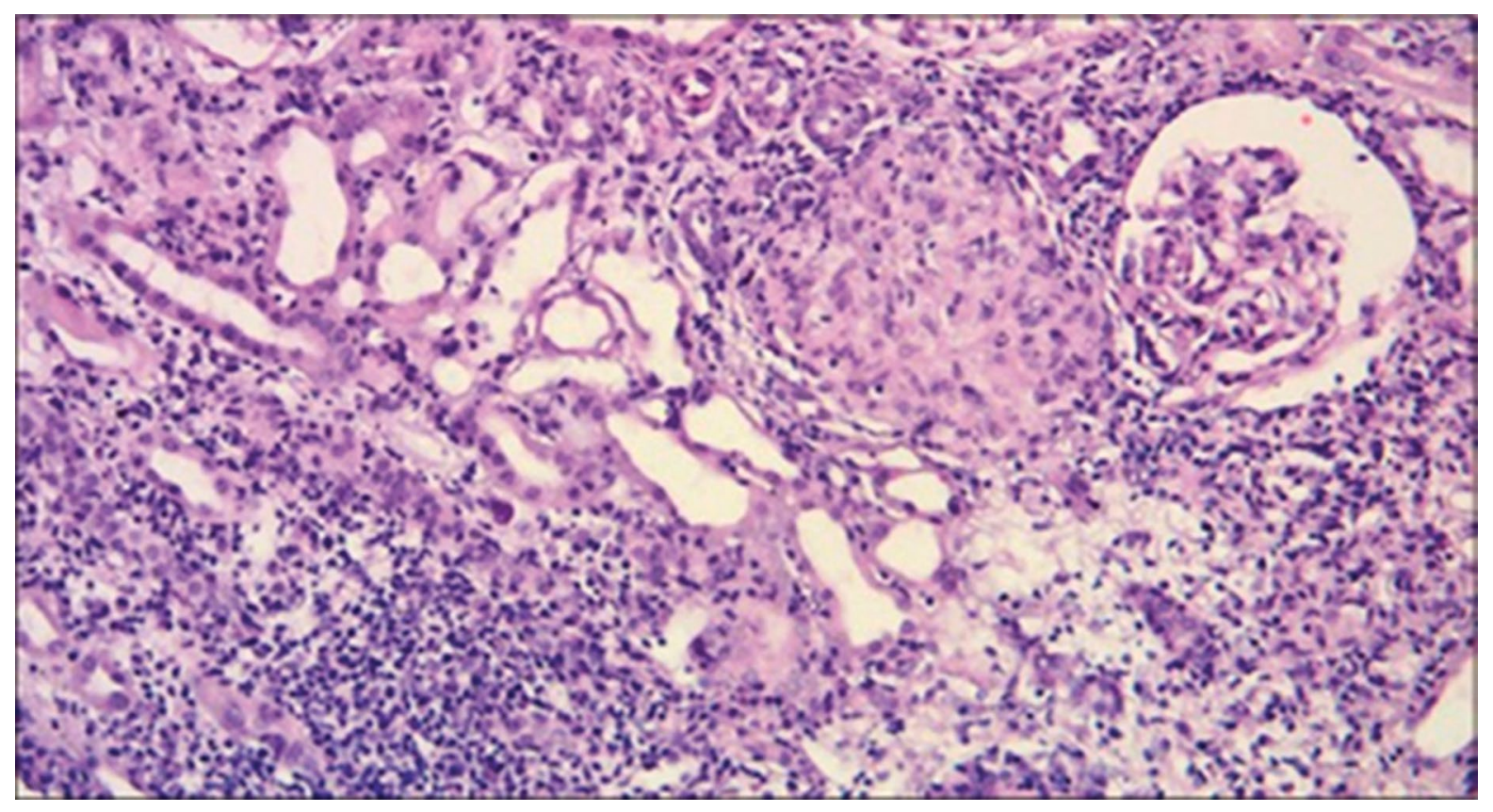

Рис. 2. Перигломерулярні, периваскулярні та перитубулярні щільні, дифузні мононуклеарні інфільтрати в паренхімі ураженої нирки при DIHS/DRESS, асоційованої з HHV-6 (periodic acid-Schiff coloration x40) (за Aatif T. зі спів.)

Hagiya H. зі спів. повідомили про розвиток DIHS/DRESS з ознаками ниркової недостатності, що розвинувся через три тижні прийому триметоприму-сульфометоксазолу у 74-річного пацієнту без очевидних причин вторинного імунодефіциту. Гістологічний аналіз тканини біоптату ураженої нирки виявив картину гранулематозного тубулоінтерстиційного нефриту, характерного для алергічних реакцій гіперчутливості сповільненого типу. Втім, ПЛР демонструвала ДНК HНV-6 в тубулярних епітеліальних клітинах нирок, що вказувало на реактивацію цього вірусного агенту [11].

Ураження нирок при онкологічних та лімфопроліферативних синдромах, індукованих герпесвірусами. Герпесвірусні агенти, особливо - гамма-герпесвіруси (EBV, HHV-8), є відомими онкогенами, що можуть індукувати розвиток злоякісних новоутворень та лімфопроліферативних синдромів, при яких може бути залученою в патологічний процес ниркова паренхіма. Godinho I. зі спів. повідомили про розвиток мембранопроліферативного гломерулонефриту та інтерстиційного нефриту у 24-річного імунокомпетентного пацієнта як наслідку EBV-індукованого гемофагоцитарного синдрому. ДНК ЕВV була ідентифікована в паренхімі нирки методом ПЛР in situ. Відзначалися гарячка, спленомегалія, біцитопенія, гіперферитинемія, гіпертригліцеридемія, підвищений рівень розчинної молекули CD25 [9]. Story M.T. зі спів. описали розвиток саркоми Капоші HHV-8-етіології з вторинною інфільтрацією ниркової паренхіми у реципієнта алогенної нирки з подальшим метастатичним ураженням інших органів і систем організму пацієнта [28].
Вторинна реактивація герпесвірусів у реципієнтів алогенної нирки. Можливість реактивації CMV у реципієнтів алогенної нирки, так само як необхідність моніторингу і лікування цієї інфекції, добре відомі в нефрології та трансплантології. Наразі накопичені докази, що і герпесвіруси інших видів також можуть зазнавати реактивації в умовах імуносупресії, що розвивається у реципієнтів алогенної нирки у зв'язку з прийомом цитостатичних препаратів для попередження імунної реакції відторгнення трансплантату. Можлива як реактивація ендогенного вірусу, так і формування реактивованої інфекції екзогенним патогеном, що занесений в організм реципієнта разом з трансплантатом. Остання ситуація 3 великою ймовірністю може трапитися при пересадці нирки від серопозитивного донора серонегативному реципієнту. Ці реактивоані герпесвірусні інфекції можуть уражати як сам нирковий трансплантат, так й інші органи та системи реципієнта, а також індукувати онкологічні, лімфопроліферативні ускладнення та ініціювати імунну реакцію відторгнення трансплантату.

Zeidan J.H. зі спів. описали випадок розвитку реактивованої HSV-2-інфекції з формуванням гепатиту, езофагіту, шкірного висипу та ерозування слизової оболонки ротової порожнини при пересадці алогенної нирки від серопозитивного донора серонегативному реципієнту. Таким чином, йшлося про занесену із трансплантатом екзогенну герпесвірусну інфекцію [35]. Hanna R.M. зі спів. повідомили про три випадки реактивації ендогенного VZV у реципієнтів алогенної нирки, причому інфекція проявлялася у вигляді атипо- 
вих шкірних висипань, характерних для імуноскомпрометованих осіб [12]. Ito K. зі спів. повідомили про вперто рецидивний афтозний стаматит, викликаний мікстінфекцією, сформованою CMV, HSV-1 та Candida albicans, у реципієнта алогенної нирки [14].

al-Khaldi N. зі спів. описали реактивовану мікстінфекцію, сформовану HHV-6 і парвовірусом В19, з картиної персистуючої гарячки та екзантеми, у 7-річного реципієнта алогенної нирки через два тижні після застосування антитимоцитарного імуноглобуліну [6]. Rossi C. зі спів. повідомили про фатальну реактивовану HHV-6-інфекцію, що розвинулася, починаючи з 20 доби після пересадки алогенної нирки. Відзначався розвиток вірус-індукованого гемофагоцитарного синдрому 3 ураженням печінки, червоного кісткового мозку та ЦНС. ДНК НHV-6 ідентифікували в лейкоцитах крові, цереброспінальній рідині, аспіраті червоного кісткового мозку та бронхоальвеолярному лаважі. Терапія в/в імуноглобуліном, ганцикловіром та фоскарнетом призвела до деякої стабілі- зації стану пацієнта, однак той зрештою помер від важкої, дисемінованої грибкової суперінфекції, сформованої Aspergillus fumigatus та Candida albicans [25].

Lin W.C. зі спів. описали розвиток CD8+ гамма/дельта Т-клітинної лімфоми, індукованої HHV6 , у реципієнта алогенної нирки. Розвиток вірусіндукованої пухлини пов'язали з вторинною імуносупресією, асоційованою з трансплантацією [17].

Sánchez-Ponce Y. зі спів. у спеціально спланованому клінічному дослідженні, в якому аналізували 495 пар зразків лейкоцити крові-плазма крові, отриманих від 34 реципієнті алогенної нирки або печінки, показали, що реактивація CMV і HHV-6, так само як і розвиток реактивованих коінфекцій EBV+HHV-7 та EBV+HHV-6+HHV-7 acoційовані з розвитком імунної реакції відторгнення трансплантату $(R R=40,33(p=0,0013), 5,60(p=$ $0,03), 5,60(p=0,03)$ та 17,64 ( $p=0,0003)$, відповідно) (рис. 3) [26].
Frequencies of positive samples for each virus

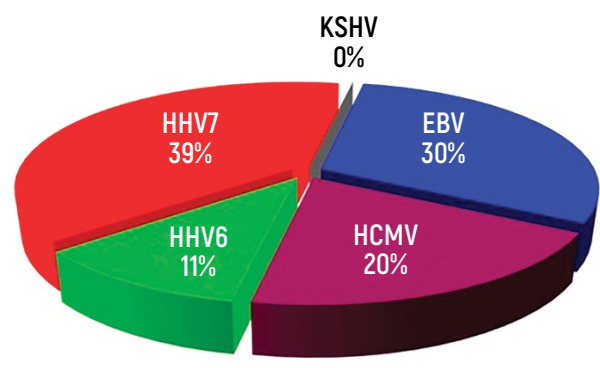

(a)
Example of viral loads detected in one patient

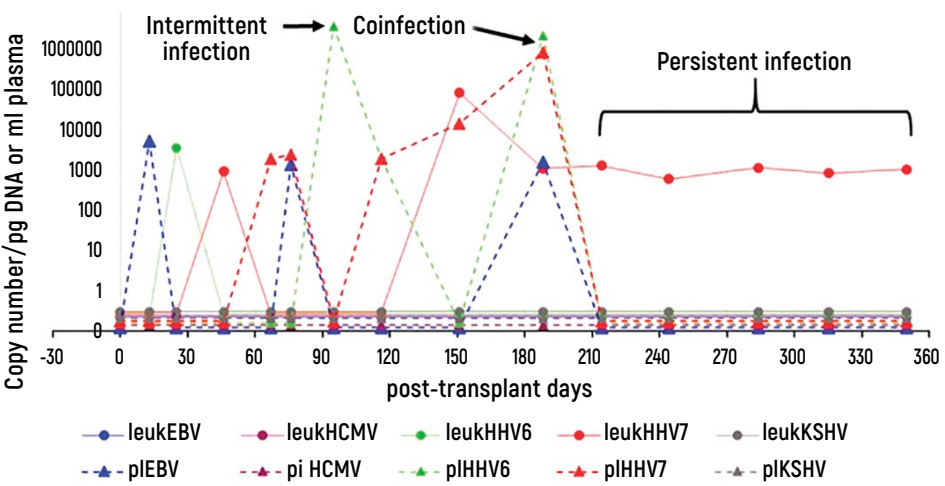

(b)

Рис. 3. Результати симультантного визначення ДНК герпесвірусів різних видів в крові у реципієнтів алогенної нирки або печінки за даними мультиплексної кількісної real-time ПЛР (за Sánchez-Ponce Ү. зі спів.)

Вторинна реактивація герпесвірусів при хворобах нирок. Важкі хвороби нирок, особливо ті, що супроводжуються нирковою недостатністю, здатні призводити до вторинної імуносупресії в організмі людини, що може стати передумовою для реактивації герпесвірусів з латентного або персистуючого стану внаслідок послаблення імунного нагляду.

YU T.M. зі спів. оприлюднили результати національного когортного контрольованого клінічного дослідження за участю майже 9 тисяч пацієнтів, що продемонстрували різке підвищення ризику формування важких інфекцій, викликаних VZV, у пацієнтів з полікістозною хворобою нирок $(\mathrm{aHR}=$ $1,97 ; 95 \% \mathrm{Cl}=1,17-3,31)[34]$.
Habuka М. зі спів. описали випадок фатальної дисемінованої VZV-інфекції з поліорганним ураженням у пацієнта з люпус-нефритом при застосуванні імуносупресивної терапії мікофенолатом мофетилом та глюкокортикостероїдом у високій дозі, які були призначені для пригнічення активності автоімунного процесу в нирковій паренхімі (рис. 4) [10]. 

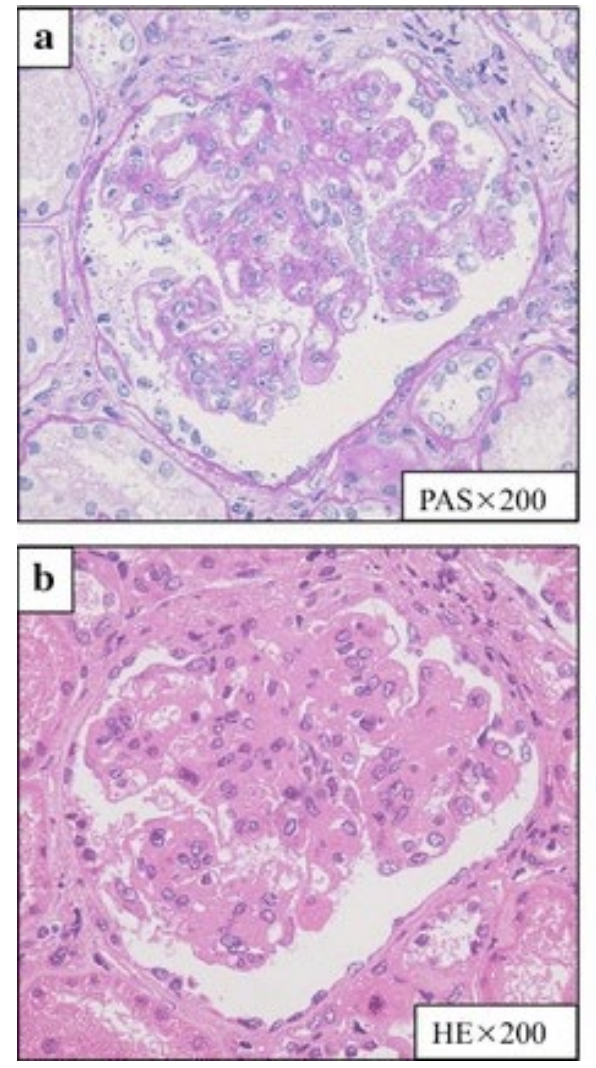

Рис. 4. Патологічні зміни в біопсійних зразках паренхіми ураженої нирки при світловій $(a, b)$ та імунофлуоресцентній мікроскопії (с) у пацієнта з люпус-нефритом під час розвитку дисемінованої VZV-інфекції (за Habuka М. зі спів.)

Chung A.B., Fas N. повідомили про випадок успішного застосування ацикловіру для лікування HSV-1-гепатиту у пацієнта з люпус-нефритом, що приймав циклофосфамід для пригнічення автоімунної реакції. Автори провели мета-аналіз аналогічних клінічних випадків, опублікованих в науковій періодичній літературі, дійшовши висновку, що ацикловір є препаратом вибору в таких клінічних ситуаціях [7].

Реактивована герпесвірусна інфекція може загострювати та посилювати прояви передіс-

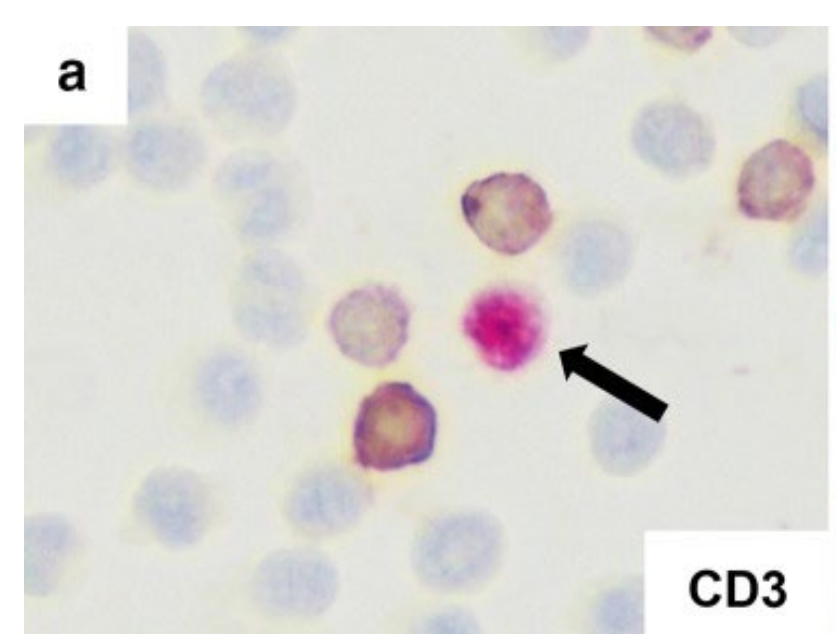

нуючої хвороби нирок, що призвела до вторинної реактивації опортуністичного патогену. Так, Sato Y. зі спів. повідомили про екзацербацію IgA-нефропатії одразу ж після реактивації EBVінфекції з розвитком ознак ниркової недостатності. Було ідентифіковано EBER-1 в CD20+ лімфоцитах крові за допомогою гібридизації in situ (рис. 5) та ДНК вірусу в клітинах ниркової паренхіми шляхом ПЛР [27].

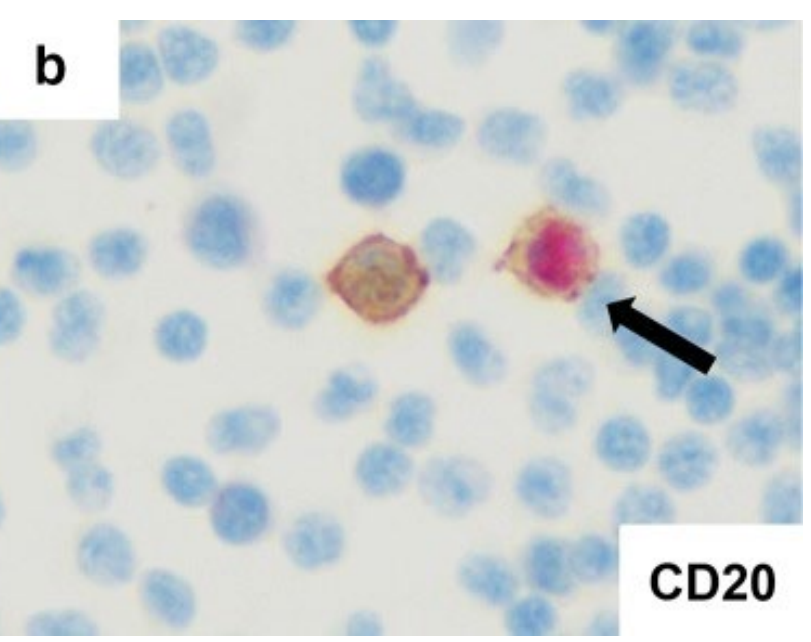

Рис. 5. Результати ідентифікації EBER-1 EBV шляхом гібридизації in situ в CD20+ (b), однак не в CD3+ (a) лімфоцитах в мазку крові під час загострення IgA-нефропатії (за Sato Y. зі спів.) 
Проблеми переносимості протигерпетичних хіміопрепаратів у пацієнтів з нирковою недостатністю. Ациклічні аналоги нуклеозидів, що застосовуються наразі для лікування реактивованих герпесвірусних інфекцій, можуть мати несприятливий профіль переносимості у пацієнтів з порушеннями екскреторної функції нирок, що має бути підставою для перерахунку доз препаратів і тривалості курсів терапії [2]. Matsukawa M. К. зі спів. повідомили про розвиток енцефалопатії, викликаної ацикловіром в дозі 800 мг на добу перорально, з пригніченням свідомості, галюцинаціями та астеріксісом у 77-річного пацієнта з оперізуючим герпесом, що протягом тривалого часу мав хронічну ниркову недостатність і з цього приводу перебував на перитонеальному діалізі [21]. Murakami T. зі спів. описали випадок нейро- та нефротоксичності при застосуванні середньотерапевтичної дози валацикловіру per os для лікування оперізуючого герпесу у 66-річної пацієнтки 3 хронічною нирковою недостатністю. Після прийому протигерпетичного хіміопрепарату у пацієнтки розвинулася кома, відзначалася висока гіперкреатинінемія та помірна гіпонатріємія, які швидко були усунені після відміни противірусного лікування (рис. 6) [24].

Висновки. Герпесвірусні агенти є активними фігурантами етіології та патогенезу багатьох хвороб нирок у людей. Згідно з накопиченими дотепер доказами, герпесвіруси всіх відомих видів можуть бути залученими до розвитку патології сечовидільної системи в організмі людини. їх реактивація із латентного або персистуючого стану зазвичай відбувається в умовах імуносупресії, тому імуноскомпрометовані пацієнти з нефрологічними проблемами $є$ групою ризику з формування ускладнень, зумовлених герпесвірусами.

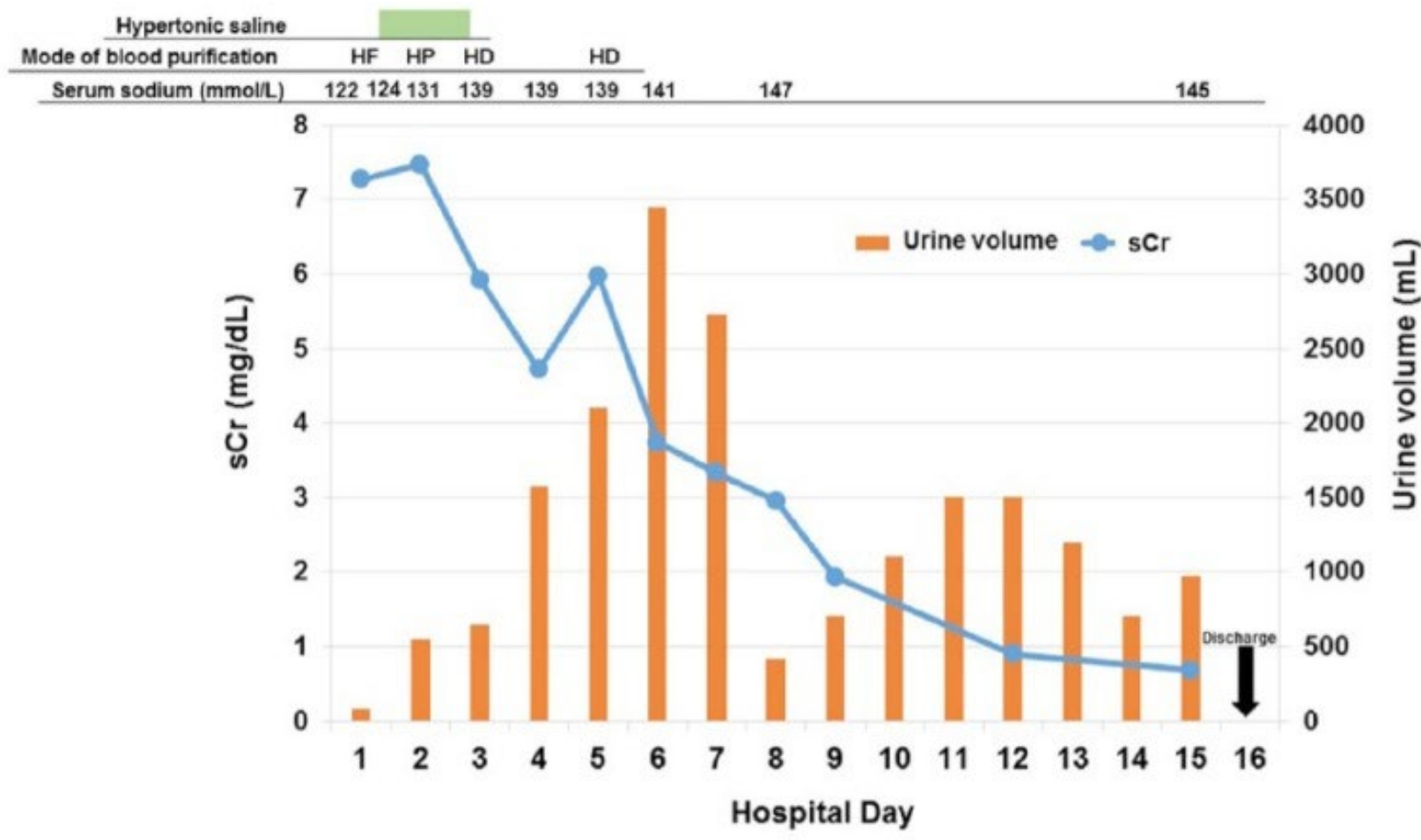

Рис. 6. Динаміка сироваткової концентрації креатиніну (sCr), осмолярності крові та об'єму добової сечі протягом курсу лікування у пацієнта з валацикловір-індукованою нефротоксичністю (за Murakami T. зі спів.)

Особливістю герпесвірусних інфекцій $€$ складний механізм паразитування і взаємодії з організмом хазяїна, що визначає безпрецедентну можливість викликати ураження ниркової паренхіми за допомогою багатьох принципово різних патогенетичних механізмів. Йдеться про прямі та непрямі шляхи вірус-індукованого ураження нирок. Прямі шляхи пов'язані з безпосереднім пошкодженням паренхіми нирок шляхом реалізації цитопатичної дії вірусів та цитотоксичної противірусної імунної відповіді. Наразі описані інтерстиційні нефрити і гломерулонеф- рити герпесвірусної етіології як у пацієнтів з імуносупресією, так і в осіб без очевидних ознак вторинного імунодефіциту. Непрямі механізми пошкодження зумовлені здатністю герпесвірусів індукувати важкі автоімунні, імунозапальні, алергічні, лімфопроліферативні та онкологічні ускладнення, при яких так чи інакше може уражатися тканина нирок. Нефрологи мають бути добре поінформовані з проблем герпесвірусних інфекцій людини і вживати належних заходів зі своєчасної діагностики та лікування випадків реактивації герпесвірусних агентів у пацієнтів 
з патологією нирок. Імунологічне обстеження $\epsilon$ наріжним каменем такого діагностичного процесу, оскільки дозволяє ідентифікувати імунодефіцит, що став причиною втрати імунного нагляду за ендогенними герпесвірусами.

Перспективи. Залучення клінічного імунолога може бути корисне з огляду на призначення адресної імунотерапії для компенсації порушень імунного статусу і відновлення контролю над опортуністичними агентами.

\section{ЛITEPATУРA}

1. Мальцев Д.В. Герпесвірусні інфекції. К.: Центр учбової літератури, 2019. - 271 с.

2. Казмирчук В.Е, Мальцев Д.В. Рекомендации по лечению герпесвирусных инфекций человека // Український медичний часопис. 2012. - №5 (91). - C.94-107.

3. Казмирчук В.Е, Мальцев Д.В., Царик В.В. Трансформация представлений о природе гиперчувствительности к медикаментам - от аллергии к вирус-индуцированному аутоиммунитету // Иммунопатология, аллергология, инфектология (Беларусь). - 2011. - №4. - С. 87-101.

4. Казмирчук В.Е, Мальцев Д.В., Царик В.В. Трансформация представлений о природе гиперчувствительности к медикаментам - от аллергии к вирус-индуцированному аутоиммунитету // Імунологія, алергологія, інфектологія. - 2012. - №3(52). - С. 41-52.

5. Aatif T., Fatihi J., Annaz H.El., Qamouss O. et al. Allopurinol-induced Drug Reactions with Eosinophilia and Systemic Symptoms Syndrome with Interstitial Nephritis // Indian. J. Nephrol. - 2018. - Vol. 28(6). - P. 477-481.

6. al-Khaldi N., Watson A.R., Harris A., Irving W.L. Dual infection with human herpesvirus type 6 and parvovirus B19 in a renal transplant recipient // Pediatr. Nephrol. - 1994. - Vol. 8(3). P. 349-350.

7. Chung A.B., Fas N. Successful acyclovir treatment of herpes simplex type 2 hepatitis in a patient with systemic lupus erythematosus: a case report and meta analysis // Am. J. Med. Sci. - 1998. - Vol. 316(6). - P. 404-407.

8. Georgaki-Angelaki H., Lycopoulou L., Stergiou N. et al. Membranous nephritis associated with acquired cytomegalovirus infection in a 19-month-old baby // Pediatr. Nephrol. 2009. - Vol. 24(1). - P. 203-206.

9. Godinho I., Nogueira E., Jorge S. et al. Membranoproliferative glomerulonephritis and interstitial nephritis in the setting of EpsteinBarr virus-related hemophagocytic syndrome // Clin. Nephrol. - 2018. - Vol. 89(6). P. 474-479.
10. Habuka M., Wada Y., Kurosawa Y. et al. Fatal visceral disseminated varicella zoster infection during initial remission induction therapy in a patient with lupus nephritis and rheumatoid arthritis-possible association with mycophenolate mofetil and high-dose glucocorticoid therapy: a case report // BMC. Res. Notes. 2018. - Vol. 11(1). - P.165.

11. Hagiya H., Iwamuro M., Tanaka T. et al. Reactivation of Human Herpes Virus- 6 in the Renal Tissue of a Patient with Drug-induced Hypersensitivity Syndrome/Drug Rash with Eosinophilia and Systemic Symptoms (DIHS/ DRESS) // Intern. Med. - 2016. - Vol. 55(13). P. 1769-1774.

12. Hanna R.M., Abd-El-Malak F., Alnaser A. et al. Herpes Zoster in Kidney Transplant Recipients: A Series of Three Cases // Case Rep. Nephrol. Dial. - 2020. - Vol. 10(3). - P. 139-146.

13. Hemmersbach-Miller M., Duronville J., Sethi S. et al. Hemorrhagic Herpes Simplex Virus Type 1 Nephritis: An Unusual Cause of Acute Allograft Dysfunction // Am. J. Transplant. - 2017. Vol. 17(1). - P. 287-291.

14. Ito K., Okuno T., Sawada A. et al. Recurrent Aphthous Stomatitis Caused by Cytomegalovirus, Herpes Simplex Virus, and Candida Species in a Kidney Transplant Recipient: A Case Report // Transplant. Proc. 2019. - Vol. 51(3). - P. 993-997.

15. Kano K., Yamada Y., Sato $Y$. et al. Glomerulonephritis in a patient with chronic active Epstein-Barr virus infection // Pediatr. Nephrol. - 2005. Vol. 20(1). - P. 89-92.

16. Li Z.X., Zeng S., Wu H.X., Zhou Y. et al. The risk of systemic lupus erythematosus associated with Epstein-Barr virus infection: a systematic review and meta-analysis // Clin. Exp. Med. - 2019. - Vol. 19(1). - P. 23-36.

17. Lin W.C., Moore J.O., Mann K.P. et al. Post transplant CD8+ gammadelta T-cell lymphoma associated with human herpes virus-6 infection // Leuk. Lymphoma. - 1999. Vol. 33(3-4). - P. 377-384.

18. Linde A., Söderström R., Smith C.I. et al. Herpesvirus serology, aberrant specific immunoglobulin G2 and G3 subclass patterns and $\mathrm{Gm}$ allotypes in individuals with low levels of IgG3 // Clin. Exp. Immunol. - 1992. Vol. 90(2). - P. 199-203.

19. Maiese A., Russa R.L., Passaro G. et al. Fatal Epstein-Barr virus infection in an immunocompetent host: a postmortem diagnosis // Forensic. Sci. Med. Pathol. - 2020. Vol. 16(4). - P. 714-717.

20. Majumdar A., Atam V., Mishra M. et al. Rare case of post-varicella membranoproliferative 
glomerulonephritis presenting with massive proteinuria // BMJ. Case. Rep. - 2020. - Vol. 13(3). - e233084.

21. Matsukawa M.K., Suzuki Y., Ikuma D. et al. Acyclovir encephalopathy in a peritoneal dialysis patient despite adjusting the dose of oral acyclovir: a case report // Rinsho Shinkeigaku. - 2019. - Vol. 59(12). - P. 834-839.

22. Meyer P., Soëte S., Raynaud P. et al. Acute inflammatory polyradiculoneuropathy and membranous glomerulonephritis following EpsteinBarr virus primary infection in a 12-year-old girl // Arch. Pediatr. - 2010. - Vol. 17(11). P. 1535-1539.

23. Moretti M., Lava Sebastiano A.G., Zgraggen L. et al. Acute kidney injury in symptomatic primary Epstein-Barr virus infectious mononucleosis: Systematic review // J. Clin. Virol. 2017. - Vol. 91. - P. 12-17.

24. Murakami T., Akimoto T., Okada M. et al. Valacyclovir Neurotoxicity and Nephrotoxicity in an Elderly Patient Complicated by Hyponatremia // Drug Target Insights. - 2018. Vol. 12. -1177392818782899.

25. Rossi C., Delforge M.L., Jacobs F. et al. Fatal primary infection due to human herpesvirus 6 variant $A$ in a renal transplant recipient // Transplantation. - 2001. - Vol. 71(2). P. 288-292.

26. Sánchez-PonceY., Varela-Fascinetto G.,RomoVázquez J.C. et al. Simultaneous Detection of Beta and Gamma Human Herpesviruses by Multiplex qPCR Reveals Simple Infection and Coinfection Episodes Increasing Risk for Graft Rejection in Solid Organ Transplantation // Viruses. - 2018. - Vol. 10(12). - P. 730.

27. Sato Y., Furuyama K., Suzuki T. et al. Acute kidney injury in an adult patient with $\lg A$ nephropathy and chronic replicative Epstein-Barr virus infection // CEN Case Rep. - 2019. Vol. 8(4). - P. 285-291.

28. Story M.T., Sanders M.L., Bashir A.A. et al. Infiltrating Kaposi sarcoma presenting as acute kidney injury: An unexpected consequence of deliberate hepatitis C-positive organ transplantation // Transpl. Infect. Dis. - 2020. Oct 3. Online ahead of print.

29. Subat-Dezulović M., Sindifić Dessardo N., Dezulović M. et al. Postinfectious glomerulonephritis and Epstein-barr virus co-infection // Coll. Antropol. - 2010. - Vol. 34(2). P. 229-232.

30. Ueda S., Uchiyama S., Azzi T. et al. Oropharyngeal group A streptococcal colonization disrupts latent Epstein-Barr virus infection // J. Infect. Dis. - 2014. - Vol. 209(2). P. 255-264.
31. Watanabe T., Sugawara H., Tamura H. et al. Co-infection with group A Streptococci and Epstein-Barr virus presenting with acute glomerulonephritis and acute left ventricular dysfunction // Intern. Med. - 2012. Vol. 51(18). - P. 2639-2643.

32. White W.M., Tran D., Garovic V.D., Brost B. et al. Acute Interstitial Nephritis Proteinuria and Herpes Simplex Virus Hepatitis in Pregnancy Mimic HELLP Syndrome (Hemolysis, Elevated Liver Enzymes, Low Platelets) // AJP Rep. 2011. - Vol. 1(2). - P. 115-118.

33. Wynd E., Stewart A., Burke J. et al. Focal segmental glomerulosclerosis associated with acute cytomegalovirus infection in a renal transplant // Pediatr. Transplant. - 2019. Vol. 23(6). - e13538.

34. Yu T.M., Li C.Y., Chuang Y.W. et al. Risk of severe herpes zoster infection in patients with polycystic kidney disease: A nation-wide cohort study with propensity score matching analysis // Int. J. Clin. Pract. - 2020. - e13675.

35. Zeidan J.H., Casingal V., Hippen B. et al. Donor derived herpes simplex virus hepatitis in a kidney transplant recipient and review of the literature // Transpl. Infect. Dis. - 2021. e13562.

36. Zou G., Chen Y., Li W. et al. A case report of varicella-zoster virus infection associated glomerulonephritis and encephalitis // Beijing Da Xue Xue Bao Yi Xue Ban. - 2011. - Vol. 43(6). - P. 914-918.

\section{PEЗЮME}

\section{ГЕРПЕСВИРУСНЫЕ ИНФЕКЦИИ В НЕФРОЛОГИИ Мальцев Д.В.}

НМУ имени А.А. Богомольца

Институт экспериментальной и клинической медицины Киев, Украина

Вступление. Герпетические вирусы - группа оппортунистических ДНК-содержащих вирусных агентов, обладающих свойством пантропизма, то есть способностью поражать все органы и системы человеческого организма. Не исключение составляет и мочевыводящая система, поэтому нефрологи должны уделять должное внимание проблеме герпесвирус-ассоциированных поражений почек и других органов мочеотделения. Данная публикация является научным обзором результатов клинических исследований и сообщений о клинических случаях герпесвирусных инфекций у нефрологических пациентов, опубликованных в последние годы в рецензируемых периодических научных изданиях, цитируемых в авторитетных наукометрических электронных базах данных PubMed и Embase.

Цель. Статья призвана сформировать у нефрологов современное комплексное понимание проблемы герпесвирусных инфекций у пациентов с болезнями почек. 
Материалы и методы. Библиографический - проведен теоретический анализ и осуществлено обобщение данных литературы, проанализировано фактическое содержание. При исследовании использован анкетно-опросный метод, а также описание, анализ, реферирование.

Результаты и обсуждение. В статье рассмотрены данные по прямым герпесвирусным поражениям почек по типу интерстициального нефрита и гломерулонефрита. Подчеркнута необходимость дифференциальной диагностики с аналогичными поражениями почек аутоиммунной природы в таких случаях. Также приведены данные о косвенных поражениях почек, спровоцированных реактивированными герпесвирусами, включая тропные к почечной паренхиме аутоиммунные, аллергические и иммуновоспалительные реакции, индукцию синдрома опухолевого роста и развитие лимфопролиферативных синдромов, а также - герпесвирусотоксичности. Отдельно представлена информация о герпесвирусных инфекциях у реципиентов аллогенной почки. Затронуты вопросы нефротоксичности при применении специфических противогерпетических химиопрепаратов у пациентов с ХПН.

Выводы. Герпесвирусные агенты являются активными фигурантами этиологии и патогенеза многих заболеваний почек у людей. Их реактивация из латентного или персистирующего состояния обычно происходит в условиях иммуносупрессии, поэтому иммуноскомпрометированные пациенты с нефрологическими проблемами являются группой риска формирования осложнений, обусловленных герпесвирусами.

Ключевые слова: вирусы простого герпеса, варицелла-зостер вирус, вирус Эпштейна-Барр, цитомегаловирус, вирусы герпеса 6, 7, 8 типов, интерстициальный нефрит, гломерулонефрит, трансплантация аллогенной почки.

\section{SUMMARY \\ HERPESVIRUS INFECTIONS IN NEPHROLOGY Maltsev D.V.}

Bogomolets National Medical University Institute of Experimental and Clinical Medicine Kyiv, Ukraine

Introduction. Herpetic viruses are a group of opportunistic DNA-containing viral agents that have the proper- ty of pantropism, that is, the ability to infect all organs and systems of the human body. The urinary system is no exception, therefore nephrologists should pay due attention to the problem of herpesvirus-associated lesions of the kidneys and other urinary organs. This publication is a scientific review of the results of clinical studies and reports of clinical cases of herpesvirus infections in nephrological patients, published in recent years in peer-reviewed scientific periodicals cited in the authoritative scientometric electronic databases PubMed and Embase.

Goal. The article is intended to form a modern comprehensive understanding of the problem of herpesvirus infections in patients with kidney disease among nephrologists.

Materials and methods. Bibliographic - a theoretical analysis is carried out and a generalization of literature data is carried out, the actual content is analyzed. The study used a questionnaire-survey method, as well as description, analysis, abstracting.

Results and discussion. The article discusses data on direct herpesvirus kidney lesions of the type of interstitial nephritis and glomerulonephritis. The need for differential diagnosis with similar kidney lesions of an autoimmune nature in such cases is emphasized. It also provides data on indirect renal lesions provoked by reactivated herpesviruses, including autoimmune, allergic and immuneinflammatory reactions, tropic to the renal parenchyma, induction of tumor growth syndrome and the development of lymphoproliferative syndromes, as well as herpesvirus toxicity. Information on herpesvirus infections in allogeneic kidney recipients is presented separately. The issues of nephrotoxicity during the use of specific antiherpetic chemotherapy drugs in patients with chronic renal failure are discussed.

Conclusions. Herpesvirus agents are active players in the etiology and pathogenesis of many kidney diseases in humans. Their reactivation from a latent or persistent state usually occurs under conditions of immunosuppression; therefore, immunocompromised patients with nephrological problems are at risk of developing complications caused by herpes viruses.

Key words: herpes simplex viruses, varicella-zoster virus, Epstein-Barr virus, cytomegalovirus, herpes viruses $6,7,8$ types, interstitial nephritis, glomerulonephritis, allogeneic kidney transplantation.

\section{АВТОРСЬКА ДОВІДКА}

\section{Мальцев Дмитро Валерійович}

НМУ ім. О.О. Богомольця, Інститут експериментальної і клінічної медицини,

зав. лабораторією імунології і молекулярної біології

Адреса: 01601, просп. Перемоги, 34 Київ, Україна

Тел.: (068)100-85-95

E-mail: dmaltsev@ukr.net

\section{Мальцев Дмитрий Валерьевич}

НМУ им. А.А. Богомольца, Институт экспериментальной и клинической медицины,

зав. лабораторией иммунологии и молекулярной биологии

Адрес: 01601, просп. Победы, 34, Киев, Украина

Тел.: (068) 100-85-95

E-mail:dmaltsev@ukr.net

\section{Maltsev Dmytro}

Bogomolets National Medical University, Institute of Experimental and Clinical Medicine, head of laboratory of immunology and molecular biology Address: 34 Peremohy ave., Kyiv 01601, Ukraine Tel.: (068) 100-85-95 E-mail: dmaltsev@ukr.net 